\author{
Бейхан Асма \\ (Кайсери, Турция)
}

\title{
ОТЕЦ И СЫН БОЛКОНСКИЕ В РОМАНЕ Л. Н. ТОЛСТОГО «ВОЙНА И МИР»
}

\begin{abstract}
The report researches a problem of Bolkonsky's father and son in «War and Peace» by Leo Tolstoy: the relationships between Bolkonsky, his son and Andrew in the role of a father, where we can see not just a issues of the family, associated with images of Rostov and Kuragin, but also a special biblical meaning (God as the Father and God as the Son).
\end{abstract}

Keywords: the problem of father and son, family, biblical issues.

В романе Л.Н. Толстого «Война и мир» два отца и два сына Болконских. В произведении речь идет и о старом князе Болконском, его взаимоотношениях с сыном, и о князе Андрее в роли отца. При этом следует видеть не просто семейную проблематику, связанную в романе также с образами Ростовых, Курагиных, с сюжетом «Эпилога», но и отраженную в них особую библейскую тематику. Тема Бога-отца и Богасына с особой силой звучит в «Эпилоге», в эпизоде клятвы Николеньки.

Обратимся сначала к образам двух старших Болконских. Князь Николай Андреевич - человек незаурядный, один из тех, кто в XVIII веке строил мощную российскую государственность, приближенный Екатерины II, генерал-аншеф, занимавший видное положение именно благодаря своим талантам, а не стремлению сделать карьеру. Он один из тех, кто служил Отечеству и никогда не прислуживался, о чем говорит его отставка и даже ссылка при Павле. В его облике отразились черты знатного и богатого деда Л.Н. Толстого по матери, генерала Н.С. Волконского, атеиста, о котором существует легенда, что он попал в немилость, отказавшись жениться на любовнице Павла, за что и был сослан сначала в далекий северный Грумант, а затем в свое имение под Тулой.

Болконские - старинный княжеский род, Рюриковичи, аристократы, которым и царская фамилия - не указ, они по праву гордятся своим древним родом и заслугами перед Отечеством. Высокое понятие о чести, гордость, независимость, благородство и остроту ума старый князь передал по наследству и своему сыну. Оба презирают выскочек, карьеристов (типа Курагина), хотя единственное исключение Болконский, видимо, делал для старого графа Безухова, принадлежащего, по всей видимости, к новой знати, фаворитам Екатерины (прототипом его в некоторой степени был граф Безбородько). Титулы этих «новых людей», как и их богатство, были не родовыми, а пожалованными. Дружба с 
Пьером, сыном Безухова, досталась князю Андрею, видимо, тоже по наследству от дружбы его отца с отцом Пьера.

Следует отметить, что оба Болконских - разносторонне образованные, одаренные люди, которым близки идеи гуманизма и просветительства, они гуманно относятся и к своим крепостным, несмотря на внешнюю строгость и требовательность к себе и окружающим. Княжна Марья знала, что крестьяне ее отца были зажиточными, что отцом учитывались в первую очередь нужды мужиков, и это побуждает ее в первую очередь заботиться о крестьянах при отъезде из имения ввиду нашествия неприятеля. При сравнении князя Андрея и его отца, однако, забывают, что характеры и того и другого даны в развитии.

Князь Андрей, конечно, шагнул гораздо дальше Николая Андреевича, к которому питает неизменно уважение и которым восхищается (недаром он просит отца при своем отъезде на войну не оставлять внука). Болконский-отец верил в прогресс и будущее величие Родины, которому служил всеми силами. Болконский-сын - главный идеологический герой Толстого - скептически относится к государству и власти вообще. Высокая идея служения Отечеству, воодушевлявшая его отца, трансформируется у князя Андрея в идею служения миру, единения всех людей, идею всеобщей любви и объединения человечества с природой. Старый князь живет в России, а его сын ощущает себя гражданином, частью Вселенной. Он совершает подвиг, но это не подвиг патриота, это подвижничество апостола (Greenwood 1982).

И недаром Толстой наделяет его апостольским именем - Андрей, но имя это - синоним слова Россия, ведь апостол Андрей - покровитель России, предсказавший населявшим эти земли славянам великое будущее. Россия должна дать миру пример любви и непротивления злу насилием, открыть новую эпоху единения всех людей, продолжая завет Христа: «несть ни эллина, ни иудея...». Христианство было шагом вперед в духовном развитии человечества, потому что признавало всех людей братьями во Христе, сыновьями единого Бога, не выделяло какой-то избранный народ. В этом смысле толстовский апостол Андрей проклинает войну, не разделяя войны на справедливые и завоевательные. Война - это убийство, по мнению героя Л.Н. Толстого, а убийство всегда (на любой войне) противно Богу и закону любви. Во имя этих идей и принимает мученическую смерть толстовский апостол Андрей со своим полком, не сделавшим ни единого выстрела, но выстоявшим.

Надо сказать, что старый князь, сначала несколько скептически относившийся к этим апостольским, подвижническим устремлениям своих детей - сына, в котором он с тревогой находит что-то большее, чем беззаветное служение Отечеству, и христианки-дочери, и под конец жизни склонен признать их правоту. Сначала отец весьма суров к князю Андрею и княжне Марье, в которых, при всей их преданности отцу, чувствуется какая-то духовная самостоятельность. Отец издевается над 
религиозностью княжны, в сыне же он вообще с тревогой и внутренним неприятием находит какие-то непонятные для себя духовные ресурсы и стремления. Отец, например, одобряет стремление князя Андрея к славе, его отъезд на войну в 1805 году, но объясняет это желанием «Бонапарта завоевать». Привив своему сыну нравственную чистоту и серьезное отношение к семье, старик Болконский, однако, вовсе не принимает в расчет его чувство к Наташе, всячески стараясь воспрепятствовать новому браку сына. На переживания князя Андрея по поводу непонимания со стороны Лизы отец проницательно замечает и утешает сына тем, что «они все такие». Одним словом, с точки зрения старого князя, любви нет, есть только строгое исполнение долга.

Для старого Болконского в князе Андрее слишком много живой жизни, духовной утонченности, стремления к идеалу. Дочь же Болконский-отец и вовсе не хочет выдавать замуж, не веря в возможность счастья в браке, считая, что для продолжения фамилии достаточно одного внука - ребенка князя Андрея и Лизы. Однако перед смертью обычная жесткость старого князя по отношению к детям исчезает. Он просит прощения за искалеченную жизнь у дочери и заочно - у сына. Княжна Марья еще будет счастлива, а о сыне старый князь говорит перед смертью пророческие слова: «Погибла Россия!» Может быть, он только сейчас понял, что сын его принес в мир идею более великую, чем патриотизм и служение отечеству.

Продолжать идеи своего отца будет другой Николай Болконский Николенька. В «Эпилоге» ему 15 лет. Шести лет он остался без отца. Да и до шести лет мальчик немного провел времени с ним. В первое семилетие жизни Николеньки его отец участвовал в двух войнах, надолго задержался за границей из-за болезни, много сил отдал преобразовательной деятельности в комиссии Сперанского (чем был горд старый князь, наверняка, огорчившийся бы, если бы узнал о разочаровании князя Андрея в государственной деятельности). Умирающий Болконский оставляет своему сыну что-то вроде старинного зашифрованного завещания о «птицах небесных». Он не произносит этих евангельских слов вслух, но Толстой говорит, что сын князя все понял, даже больше, чем мог бы понять взрослый, умудренный жизненным опытом человек (Wilson 2001: 47). В качестве «птицы небесной», которая в Евангелии представляет собой символ души, не имея «образа и формы», но составляя одну сущность - любовь, - приходит, как и обещал, князь Андрей к Николеньке уже после своей смерти. Мальчику снится Отец любовь к людям, и Николенька дает клятву принести себя в жертву (недаром вспоминается Муций Сцевола) по повелению Отца (Omeu слово, написанное с большой буквы неслучайно).

Так «Война и мир» завершается темой Отца и Сына, темой апостольского служения Богу, темой единения людей. Толстой не дает отчетливых контуров христианской идеи, потому что Андрей у него - 
апостол новой, толстовской религии. Это подробно показано в книге Б.Бермана «Сокровенный Толстой». Но главное, что тема Отца и Сына, очень важная для русской литературы («Отцы и дети»), в «Войне и мире» развернута не как тема блудного сына, а как тема божественного служения Бога-сына Богу-отцу.

\section{Литература}

Greenwood, Nathan. Russian Philosophy // American Psychological Review, Vol.3. New-Jersey, 1982. P. 147-162.

Wilson, Steve. Tolstoy and Philosophy. Pubb Publishing House. Chicago, 2001. 